DOI: 10.35340/2308-104X.2019.82-1-14

\section{ГЕНЕЗА ПОНЯТТЯ \\ ЦИВІЛЬНИЙ КОНТРОЛЬ НАД \\ СИЛОВИМИ ТА \\ СПЕЦІАЛЬНИМИ \\ СТРУКТУРАМИ ДЕРЖАВИ У \\ ВІТЧИЗНЯНІЙ НАУЦ \\ ДЕРЖАВНОГО УПРАВЛННЯ}

\author{
CAВКА I. I., \\ здобувач Інституту підготовки \\ кадрів ДСЗУ, полковник, учасник \\ ATO
}

\author{
GENESIS CONCEPT OF CIVIL \\ CONTROL OVER THE POWER \\ AND SPECIAL STRUCTURES \\ OF THE STATE IN THE \\ DOMESTIC SCIENCE OF THE \\ STATE ADMINISTRATION
}

\author{
SAVKA I., \\ applicant at the Ukrainian State \\ Employment Service Training \\ Institute, Colonel, participant in \\ the anti-terrorist operation
}

\begin{abstract}
В статті автор розкриває тенезу поняття цивільний контроль на силовими та спеціальними структурами держави у вітчизняній науці, аналізує вклад вітчизняних та зарубіжних вчених у дослідження даної проблематики. Виокремлено основні засади та завдання иивільного контролю, напрямки його реалізації. Досліджено саму дефініиію изього поняття.

Ключові слова: ичивільний контроль силові та спеціальні структури держави, військова організачія держави, начіональна безпека держави.

В статье автор раскрывает генезис понятия гражданский контроль над силовыми и специальными структурами государства в отечественной науке, анализирует вклад отечественных и зарубежных ученых в исследование данной проблематики. Выделены основные принципь и задачи гражданского контроля, направления его реализации. Исследовано дефиницию этого понятия.

Ключевые слова: гражданский контроль, силовые и специальные структуры государства, военная организация государства, национальная безопасность государства.

In the author of the article, the author of the genesis of understanding of civil control on the security forces and special structures of the state in military sciences, analysis of the contribution of foreign and foreign countries in this issue of this problem. The basic principles and tasks of civil control, directions of its realization are singled out. The definition of this concept is studied.
\end{abstract}

Keywords: civil control, power and special power structures, military power, national security bearers.

Постановка проблеми. Цивільний (іноді вживають поняття демократичний, громадянський) контроль над силовими та спеціальними структурами держави є ознакою усталеної демократії країн, що мають закріплені як на законодавчому рівні так і традиційно правові норми цього контролю. Україна лише поволі, особливо після Помаранчевої революції та Революції 
Гідності стає на шлях побудови демократичного суспільства. Тому для недопущення узурпації влади, посилення поліцейських функцій у державі, приходу до влади радикально налаштованих елементів варто більш грунтовно дослідити поняття цивільний (демократичний) контроль над силовими та спеціальними структурами держави 3 метою організації їх функціонування у демократичному режимі.

Аналіз останніх досліджень та публікацій. Тема демократичного цивільного контролю над військовою та правоохоронними сферами завжди була предметом уваги сучасної української науки. До неї у різні часи зверталися П. Ворона [2-3], В. Горбулін [7], О. Котелянець [11], О. Маркєєва [12], О. Разумцев [15], М. Требін [17] та багато інших. Цікаві і змістовні матеріали 3 питань цивільного контролю регулярно публікуються Центром О. Разумкова в журналі «Національна безпека і оборона». Значний інтерес у цьому контексті становлять роботи закордонних авторів, зокрема воєначальника i вченого М. Гареєва (РФ) [3], представників західних наукових шкіл К. Донеллі [8-10], Д. Шерра [23-25] та інших.

Мета статmі в дослідженні генези самої дефініції цивільний контроль на силовими та спеціальними структурами держави у вітчизняній науці, розуміння якої знаходиться на перетині багатьох суспільно-гуманітарних наук державного управління, політології, юриспруденції та права, тощо.

Виклад основного матеріалу. Термін "цивільний контроль над армією" (civilian control) є дослівним перекладом 3 англійської мови, у смисловому перекладі означає не лише контроль, а, перш за все, управління [20]. Адже контроль - це функція управління, яка забезпечує визначення правильності управлінських рішень, напрями здійснення необхідних коректив і відповідність дій персоналу [2]. Цивільний контроль над силовими структурами - така ж важлива ознака демократії, як свобода слова, дотримання прав людини та громадянське суспільство Тривалий час основний зміст цивільного контролю розуміли, як контроль над військовими 3 боку цивільних осіб. Показником наявності такого контролю було прийнято вважати: цивільну особу на чолі силових структур; відкрите обговорення оборонного бюджету; відсутність заборонених зон у військовій сфері для 3МI; право державних та громадських організацій вимагати звіту від військових з усього спектра питань, включно і спеціальних; обмеження політичних прав військовослужбовців та ін.

Відповідно до діючої «Стратегії національної безпеки України», вдосконалення системи демократичного цивільного контролю над органами сектору безпеки і оборони є одним із основних напрямів державної політики національної безпеки сучасної України [18]. Україна взяла на себе міжнародні зобов'язання встановити демократичний контроль над силовими структурами. Це зафіксовано у таких документах: «Партнерство заради миру: рамковий документ», «Хартія про особливе партнерство між Україною та НАТО», а також «Кодекс поведінки стосовно воєнно-політичних аспектів безпеки», затверджений на Будапештському саміті ОБСЄ у 1994 році. На сьогодні в Україні основним документом, що регулює питання демократичного контролю, $\epsilon$ Закон України «Про демократичний цивільний контроль над Воєнною 
організацією і правоохоронними органами держави» від 19 червня 2003 року [13]. Цивільний контроль в Україні забезпечує:

будівництва; пріоритет політичних підходів до вирішення питань військового

дотримання законності в діяльності усіх складових частин воєнної організації та правоохоронних органів держави;

підтримання політичної стабільності в суспільстві, створення умов, які унеможливлюють використання Збройних сил України (ЗСУ) та інших військових формувань, правоохоронних органів для обмеження прав і свобод громадян або з метою повалення конституційного ладу, усунення органів влади чи перешкоджання їх діяльності, а також в інтересах окремих осіб, партій, громадських організацій;

попередження та недопущення порушень конституційних прав i свобод, захист законних інтересів громадян України, які перебувають на службі у ЗСУ, інших військових формуваннях та у правоохоронних органах, осіб, звільнених з військової служби, а також членів їхніх сімей.

урахування громадської думки, пропозицій громадян та громадських організацій при обговоренні й ухваленні рішень 3 питань діяльності ЗСУ, інших військових формувань, правоохоронних органів та посадових осіб у сфері оборони, національної безпеки, зміцнення громадського порядку i законності.

виділення відповідно до законів у необхідних обсягах і раціональне використання бюджетних коштів, спрямованих на утримання і функціонування воєнної організації та правоохоронних органів держави, зокрема на реформування ЗСУ.

використання за цільовим i функціональним призначенням державного майна, переданого в управління ЗСУ та іншим військовим формуванням, а також правоохоронним органам.

своєчасне, повне і достовірне інформування органів державної влади та суспільства про діяльність ЗСУ, інших військових формувань, правоохоронних органів, забезпечення іiі відповідності вимогам Конституції і законів України, нормам міжнародного права, реальній військово-політичній i криміногенній ситуації, завданням забезпечення надійної оборони і безпеки держави, зміцнення громадського порядку [21]. Вважається, що цивільний контроль має дві основні мети, вага яких $є$ різною залежно від специфіки конкретної країни, від іiі демократичних традицій чи то відсутності таких, від внутрішньо- та зовнішньополітичної ситуації.

1. Для усталених демократій, 3 виробленими та апробованими часом моделями взаємовідповідальної комунікації між цивільним суспільством та владними інституціями основною метою $\epsilon$ сприяння подоланню зовнішніх загроз, а супутньою проблемою - «спротив матеріалу», себто скептицизм військового керівництва стосовно компетентності, експертного потенціалу «цивілів», негнучкість бюрократичних структур військових інституцій.

2. Для держав зі менш розвиненими демократичними практиками та інституціями не менш важливою метою цивільного контролю є становлення його як запобіжника від зловживання «озброєною владою» своїми 
повноваженнями і можливостями, у діапазоні від окремих локальних порушень людських і громадянських прав та свобод і аж до спроб збройних переворотів.

Проблеми національної безпеки України перебувають сьогодні в центрі уваги керівництва держави, міждержавних утворень та громадських організацій. I це зрозуміло, адже середовище безпеки, в якому ми живемо, нестабільне та містить у собі чимало загроз і викликів. Аналіз політологічної та соціологічної літератури, періодичних видань свідчить про недостатнє комплексне висвітлення проблем цивільного контролю силових структур держави у нашому суспільстві або про однобічне тлумачення їх в контексті «цивільного контролю» над армією.

У вітчизняному законодавстві закріплено декілька форм контролю, що застосовується у цій сфері. У Законі України «Про національну безпеку України» зазначається, що «демократичний цивільний контроль - комплекс здійснюваних відповідно до Конституції i законів України правових, організаційних, інформаційних, кадрових та інших заходів для забезпечення верховенства права, законності, підзвітності, прозорості органів сектору безпеки i оборони та інших органів, діяльність яких пов'язана 3 обмеженням у визначених законом випадках прав і свобод людини, сприяння їх ефективній діяльності й виконанню покладених на них функцій, зміцненню національної безпеки України» [14].

У науковій літературі «громадський контроль - різновид контролю, система відносин громадянського суспільства 3 державою, яка грунтується на підзвітності органів публічної адміністрації недержавними структурами та окремими особами (громадськими організаціями, пересічними громадянами, аналітичними центрами, засобами масової інформації тощо), сукупність дій недержавних структур, окремих осіб, що здійснюється на диспозитивних засадах, наслідки яких мають рекомендаційний характер і полягають у перевірці законності діяльності публічної адміністрації, стану дотримання прав, свобод, інтересів фізичних та юридичних осіб під час виконання нею своїх повноважень у сфері національної безпеки України» [16].

Державотворчий потенціал соціальних відносин у воєнній сфері суспільства визнавався більшістю мислителів античності, середньовіччя та нового часу (Н. Макіавеллі, Ф. Клаузевиц та інші). Перша за новітню історію спроба систематизовано розглянути цивільно-військові відносини належить відомому американському досліднику С. Хантінгтону [19]. Він розробив теоретичний каркас вивчення цього суспільного явища та процесу. Моделі цивільно-військові відносини різних за державним устроєм країн та їх науковий аналіз проведений також у наукових працях зарубіжних вчених, таких як С. Олійник, К. Райс (США), А. Бабанов, О. Владіміров, А. Волеводз, Ю. Дерюгін, Б. Порфір’єв, В. Серебрянніков (РФ) та інших.

Дослідження проблем цивільно-військові відносини в Україні носять фрагментарний або кон'юнктурний характер, тобто вмотивовуються виходячи із конкретної сьогоденної потреби - розробки і прийняття Конституції України, зміни чинного законодавства 3 військових питань, вступу України до загальноєвропейських структур [6]. 
Одним 3 перших в Україні систематизовані погляди на цивільний контроль як необхідний атрибут демократичної держави виклав у 2000 році М. Требін [17]. На основі аналізу досвіду держав автор робить висновок про те, що невизначеність статусу армії в суспільстві, слабкість законодавчої бази функціонування i розвитку ЗСУ, соціальна i правова незахищеність військовослужбовців і членів їх сімей роблять військовослужбовців заручниками обставин і ослаблюють обороноздатність держави. I навпаки, ефективний механізм відповідальності політиків за наслідки військової реформи сприяв би уникненню спроб перекладання такої відповідальності лише на армію.

Відомий вчений В. Горбулін також розглядав питання впровадження демократичного цивільного контролю над воєнною сферою [7]. Він вважає, що вирішення цього завдання дасть змогу уникнути відомчих перекосів та стане запорукою спільної відповідальності за впровадження прийнятих рішень. При цьому термін «контроль» означає не лише право доступу до інформації, а й активну участь у визначенні функцій і завдань силових структур, забезпеченні їх належними ресурсами, соціальним захистом тощо.

Ідеальної системи контролю не існує навіть у країнах навіть 3 великим досвідом його існування. Це твердження поділяють багато вітчизняних та закордонних дослідників (Л. Бобрицький, О. Бодрук, П. Ворона, В. Гречанінов, Г. Крючков, Г. Перепелиця, М. Требін, В. Шарий, Д. Шерр, Х. Юнг та ін.). Наполегливо постає потреба визначити суть цивільного (громадянського) контролю, чітко сформулювати його цілі, засоби та методи реалізації. Це дасть змогу уникнути серйозних методологічних помилок під час аналізу громадянського контролю над силовими структурами як соціального явища. Це особливо важливо, оскільки існує кілька тлумачень змісту громадянського контролю. Так, дослідник А. Арбатов зводить громадянський контроль до трьох чинників, якими $є$ : громадянський міністр оборони; широка участь парламенту в здійсненні політики i контролю за військовим бюджетом; максимальна відкритість інформації з військових питань. По суті, в даному разі контроль обмежується функціями інститутів держави та сферою функціонування міністерства оборони.

Поглиблення демократичних процесів в Україні ставить перед науковцями низку постійно поновлюваних питань, які потребують нагального вирішення. Зокрема, сьогодення вимагає переосмислення характеру взаємин між громадянським суспільством та державою, аналізу динамічних змін ступеня відкритості діяльності державних органів та посадових осіб, постійного моніторингу сучасних світових та національних тенденцій вдосконалення впливу громадськості на інститути публічно-політичної влади.

Проголошене Конституцією України формування демократичної, правової, соціальної держави можливе лише за умов системного реформування базових сфер соціальної життєдіяльності, гарантування функціональної узгодженості усіх суспільно-політичних інститутів. Одним з дієвих інструментів забезпечення останнього $є$ взаємний контроль суб'єктів громадянського суспільства та державного апарату.

Контролю в сфері владарювання присвячено велику кількість досліджень вітчизняних авторів, але переважна більшість 3 них акцентує увагу на проблемах 
державного контролю. Слід згадати науковців: В. Авер'янова, С. Алексєєва,

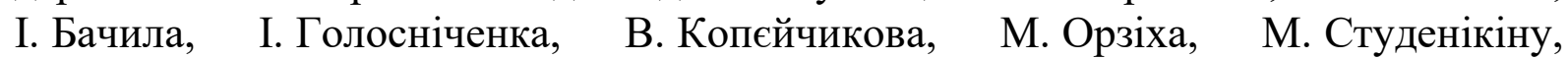
В. Чіркіна, Ю. Шемшученка, В. Юсупова та ін. Що стосується недержавного контролю, то він почав активно досліджуватися лише в останні роки. Різним його аспектам присвячені роботи вчених О. Андрійка, А. Бірюченка, В. Гаращука, С. Новикова, О. Сушинського, О. Федоровської, Н. Череміскіної. Раніше, за умов існування тоталітарного режиму, монопартійної політичної системи, панування комуністичної ідеології, не існувало необхідного соціального та світоглядного підгрунтя для створення реально функціонуючого демократичного контролю над владою, хоча окремі питання народного, громадського контролю аналізувалися (В. Борисов, I. Дрейслер, Я. Здир, Г. Левченко, В. Мальков та іншими).

Західна теорія і практика демократії розглядає контроль суб'єктів громадянського суспільства за діяльністю владних структур як одну 3 визначальних умов існування демократичної держави. В роботах Д. Валадеса, Ю. Габермаса, Д. Кіна, К. Поппера, М. Престон, К. Ульріха, Д. Хеллоуелла розкриваються різні сторони контролю громадян над урядовцями, робиться наголос на необхідності забезпечення соціальної гармонії, заснованої на засадах соціальної паритетності, партнерських відносин між народом і владою. Особливий акцент робиться на важливості підзвітності населенню правоохоронних органів (Г. Борн, Д. Бейлі, Б. Бенсон, Р. Вебер, А. Голдсміт, Т. Джонс, Р. Свон, Б. Тейлор). Окремі питання недержавного (громадського) контролю над правоохоронними органами i, зокрема, органами внутрішніх справ, були предметом досліджень таких українських авторів, як О. Бандурка, Р. Веприцький, С. Денисюк, М. Іншин, О. Клюєв, В. Московець, О. Музичук, Ю. Римаренко, О. Ярмиш. Але достатньо комплексного, всебічного дослідження вказаної проблематики досі проведено не було

У науковій літературі констатується невисокий рівень обізнаності у питаннях цивільного контролю серед громадян. На рівні постановки проблеми у дисертації В. Шамрай сформулював рекомендації щодо створення системи демократичного контролю над збройними силами [22]. Регулювання цивільновійськових відносин в умовах перехідного політичного режиму розглядається цивільний контроль у дисертації російського вченого О. Бабанова [1]. Система цивільного контролю над збройними силами у демократичних країнах заходу стала предметом політологічного дослідження I. Храбана [20]. Дослідженню процесів державного управління у сфері національної безпеки України присвячені роботи П. Ворони, В. Горбуліна, І. Грицяка, А. Качинського, В. Ліпкана, В. Телелима, В. Почепцова, А. Падеріна, Г. Перепелиці, Т. Стародуб, Г. Ситника, А. Семенченка, А. Сіцінського, О. Суходолі, I. Храбана, Л. Чекаленко, В. Чалого та інших.

Досвід демократичних країн свідчить, що без узгодження проблем цивільного та військового управління не можливе забезпечення обороноздатності держави. У вітчизняній науковій літературі існують лише поодинокі дослідження, які в тій, чи іншій мірі стосуються проблем становлення та розвитку силових структур держави. До них слід віднести в першу чергу 
роботи В. Говорухи, В. Горовенко, О. Гриненка, А. Гриценко, С. Нечхаєва, Л. Полякова, А. Семенченко, В. Телелима, В. Шамрая [22].

Разом 3 тим, ураховуючи деякі нормативно-правові акти, слід зазначити, що у роботах вищеназваних авторів неповною мірою відображено сучасний стан системи демократичного цивільного контролю сектором безпеки i оборони України, а також констатувати порівняно невеликий інтерес до нього з боку науковців у галузі наук «Державне управління».

Висновки $i$ перспективи подальших досліджень. На наш погляд, у вітчизняній науці державного управління, дефініція «цивільний контроль над силовими та спеціальними структурами держави», як суспільний феномен, не отримала ще належного наукового висвітлення. Переважно дослідження цього поняття стосуються лише можливих функцій громадянського суспільства та органів публічної влади, але поза увагою залишається розгляд самої теорії контролю у воєнній та силовій організації держави, концепції іiі розвитку, чинників, які впливають на їі зміст і структуру, а також проблеми управління іiі складовими при виконанні особливих завдань під час впровадження правових режимів надзвичайного та воєнного стану. Варто зазначити, що без узгодження проблем цивільного та військового управління не можливе належне забезпечення обороноздатності держави.

Досить часто науковці зводить цивільний контроль силових структур до трьох чинників, якими є: цивільний міністр оборони; широка участь парламенту в здійсненні політики контролю за військовим бюджетом; відкритість інформації 3 військових питань. Але цивільний контроль не обмежується функціями державних інститутів та сферою функціонування міністерства оборони. Мають бути залучені до цього процесу й громадські структури суспільства. У подальшому варто провести чітке розмежування у дефініціях «демократичний», «громадянський», «цивільний» контроль над силовими та спеціальними структурами держави.

\section{Лimepamypa:}

1. Бабанов А. А. Силовые институты в системе политической власти правового государства (на примере ВС и МВД Российской Федерации): автореф. дис. д. полит. н.: 23.00.02 / Пограничная академия ФСБ РФ. М., 2006. 40 с.

2. Волеводз А. Г. Гражданський контроль почти не виден // Независимое военное обозрение от 21.04.2006. URL: http://nvo.ng.ru/ concepts/2006\#04\#21/1_ control.html.

3. Ворона П. В. Інститут цивільного контролю над силовими структурами держави як фактор євроатлантичної інтеграції Актуальні проблеми європейської та євроатлантичної інтеграції: матеріали 15-ї регіон. наук. практ. конф. 17 трав. 2018 р., м. Дніпро, за наук. ред. Л. Л. Прокопенка. Д: ДРІДУ НАДУ, 2018, С. 248-252.

4. Ворона П. В. Цивільний контроль над силовими структурами держави: проблематика співвідношення політики та управління. Взаємозв'язок політики і управління: теоретичний і прикладний аспект: матеріали круглого столу / за заг. ред. О. Б. Кірєєвої. Д.: ДРІДУ НАДУ, 2018. С. 29-34. 
5. Гареев М. А. Система военного управления. Военно-промышленный курьер. 28 января 2004. №3 (20).

6. Говоруха В. В. Механізм державного управління цивільновійськовими відносинами Матеріали першого міжнародного наукового конгресу Державне управління та місиеве самоврядування. Харків. Вид-во УАДУ (Харківській філіал), 2001. С. 36-37.

7. Горбулін В. П. Реформа воєнної організації держави. Концептуальні підходи. Дзеркало тижня. 8 грудня 2001. №48 (372).

8. Донеллі К. Нове обличчя європейських збройних сил в XXI столітті. Національна безпека і оборона. 2002. №5. С. 59-64.

9. Донеллі К. Перетворення у галузі оборони у нових демократичних державах. Наука і оборона. 1997. №1-2. С. 15-21.

10. Донеллі К., Грін Д. Головні принципи сучасного військового будівництва в контексті реформування сфери безпеки і оборони в Україні Національна безпека і оборона. 2003. №7. С. 54-62.

11. Котелянець О. О. Шляхи підвищення ефективності демократичного цивільного контролю над сектором безпеки URL: http://defpol.org.ua/site/ index.php/uk/arhiv/obonoglyad/11530-2012-08-13.

12. Маркєєва О. Стан та перспективи реформування сектору безпеки i оборони України у нових політичних реаліях. Аналітична записка. URL: http://www.niss.gov.ua/articles/394.

13. Про демократичний цивільний контроль над Воєнною організацією i правоохоронними органами держави: Закон України від 19.06.2003 № 975-IV Вісник Верховної Ради Украӥни. 2003. №46. Ст.366.

14. Про національну безпеку України: Закон України від 21.06.2018 № 2469-VIII. Голос України. 2018. № 122.

15. Разумцев O. Г. Збройні Сили України та суспільство URL: http://defpol.org.ua/site/index.php/ru/arhiv/kolonkaavtora/4330-2011-02-02-09-05 -54.

16. Службове право України. Словник термінів / за заг. ред. Т. О. Коломоєць, В.К. Колпакова. Запоріжжя, 2017. С. 123.

17. Требін М. Механізми цивільного контролю над Збройними Силами. Людина і політика. 2000. № 3. С. 19-23.

18. Указ Президента України від 08.06.2012 №389/2012 «Про рішення Ради національної безпеки і оборони України від 8 червня 2012 року «Про нову редакцію Стратегії національної безпеки України». URL: http://zakon2.rada.gov.ua/laws/show/389/2012.

19. Хантінгтон С. Політологія. URL: https://polityslovo.wordpress.com/.../ с-хантінгтон.

20. Храбан I. А. Цивільний контроль над збройними силами в демократичній державі (досвід США і проблеми України): автореф. дис. к.політ.н.: 23.00.02 / Київський ун-т ім. Т. Шевченка. Київ, 1999. 19 с.

21. Цивільний контроль. Що таке демократичний цивільний контроль. URL: civilian.defence-reforms.in.ua/what_is_democratic_civilian.

22. Шамрай В. О. Державне управління військовими формуваннями Воєнної організації: стан та тенденції розвитку в сучасній Україні: автореф. дис. д.держ.упр.: 25.00.03 / УФДУ. Київ, 1999. 38 с. 
23. Шерр Д. Вимоги НАТО та Європейського Союзу щодо демократичного контролю над збройними силами. Реформування Збройних Сил України: пріоритети, передумови та перспективи за матеріалами міжнародних семінарів «Реформування Збройних Сил України. Потреби у змінах», Київ, 14-15 лютого 2000 р. та «Відносини між збройними силами, суспільством і державою», Київ, 22-23 червня 2000 р. К., 2001. С. 92.

24. Шерр Д. Реформа сектора безпеки в Україні: західний погляд. Джеймс Шерр Матеріали та документи міжнародного семінару 17-18 листопада «Освітні аспекти реалізації Цільового плану Україна НАТО 2004 в структурах сектору безпеки держави». Дніпропетровськ, 2004. С. 28-32.

25. Шерр Д. Трансформація сектора безпеки. Дзеркало тижня. 2004. 12-18 червня. №23 (498).

\section{References:}

1. Babanov A. A. (2006) Silovyye instituty v sisteme politicheskoy vlasti pravovogo gosudarstva (na primere VS i MVD Rossiyskoy Federatsii): avtoref. dis. d. polit. n.: 23.00.02 / Pogranichnaya akademiya FSB RF.

2. Volevodz A. G. Grazhdans'kiy kontrol' pochti ne viden // Nezavisimoye voyennoye obozreniye ot 21. 04. 2006: available at: // nvo.ng.ru/concepts/ $2006 \# 04$ \#21/1_control.html.

3. Vorona P. V. (2018) Instytut tsyvil'noho kontrolyu nad sylovymy strukturamy derzhavy yak faktor yevroatlantychnoyi intehratsiyi // Aktual'ni problemy yevropeys'koyi ta yevroatlantychnoyi intehratsiyi: materialy 15 -yi rehion. nauk. prakt. konf. 17 trav. 2018 r., m. Dnipro, za nauk. red. L. L. Prokopenka. D: DRIDU NADU, , pp. 248-252 (272 p.).

4. Vorona P. V. (2018) Tsyvil'nyy kontrol' nad sylovymy strukturamy derzhavy: problematyka spivvidnoshennya polityky ta upravlinnya // Vzayemozv"yazok polityky i upravlinnya: teoretychnyy i prykladnyy aspekt: materialy kruhloho stolu / za zah. red. O. B. Kiryeyevoyi. D.: DRIDU NADU,. pp. 29 - 34 (100 p.).

5. Gareyev M. A. (2004) Sistema voyennogo upravleniya Voyennopromyshlennyy kur'yer.no 3 (20).

6. Govorukha V.V. (2001) Mekhanízm derzhavnogo upravlínnya tsivíl'novíys'kovimi vídnosinami // Materíali pershogo mízhnarodnogo naukovogo kongresu Derzhavne upravlínnya ta místseve samovryaduvannya.-Kharkív: Vid-vo UADU(Kharkívs'kíy fílíal), p.36-37.

7. Gorbulín V. P. (2001) Reforma voênnoî organízatsîi derzhavi. Kontseptual'ní pídkhodi Dzerkalo tizhnya. no 48 (372).

8. Donellí K. (2002) Nove oblichchya êvropeys'kikh zbroynikh sil v KHKHÍ stolíttí Natsíonal'na bezpeka í oborona. no 5. pp. 59-64.

9. Donellí K. (1997) Peretvorennya u galuzí oboroni u novikh demokratichnikh derzhavakh Nauka í oborona. no1-2. pp. 15-21.

10. Donellí K., Grín D. (2003) Golovní printsipi suchasnogo víys'kovogo budívnitstva v kontekstí reformuvannya sferi bezpeki í oboroni v Ukraîní Natsíonal'na bezpeka í oborona. no 7 pp. 54-62. 
11. Kotelyanets' O. O. Shlyakhi pídvishchennya yefektivností demokra-tichnogo tsivíl'nogo kontrolyu nadsektorom bezpeki available at: http://defpol.org.ua/site/index.php/uk/ arhiv/obono glyad/11530-2012-08-13.

12. Markêêva O. Stan ta perspektivi reformuvannya sektoru bezpeki í oboroni Ukraïni u novikh polítichnikh realíyakh. Analítichna zapiska available at: http://www.niss. gov.ua/articles/394/.

13. Pro demokratichniy tsivíl'niy kontrol' nad Voênnoyu organízatsîêyu í pravookhoronnimi organami derzhavi: Zakon Ukraïni víd 19.06.2003 № 975-IV // Vísnik Verkhovnoï Radi Ukraïni. 2003. no. 46. - St.366.

14. Pro natsíonal'nu bezpeku Ukraïni: Zakon Ukraïni víd 21.06.2018 № 2469VIII. Golos Ukraïni. 2018. no. 122.

15. Razumtsev O. G. Zbroyní Sili Ukraïni ta suspíl'stvo. at http://defpol.org.ua/site/index.php/ru/ arhiv/kolonkaavtora/4330-2011-02-02-09-05-54.

16. Sluzhbove pravo Ukraïni: Slovnik termínív (2017) / za zag. red. T.O. Kolomoêts', V.K. Kolpakova. Zaporízhzhya.

17. Trebín M. (2000) Mekhanízmi tsivíl'nogo kontrolyu nad Zbroynimi Silami Lyudina í polítika. no. 3. pp.19-23.

18. Ukaz Prezidenta Ukraïni víd 08.06.2012 №389/2012 "Pro ríshennya Radi natsíonal'noố bezpeki í oboroni Ukraïni víd 8 chervnya 2012 roku "Pro novu redaktsíyu Strategiî́ natsíonal'noï bezpeki Ukraïni”. available at: http://zakon2.rada.gov.ua/laws/show/389/2012.

19. Khantíngton S. Politologiya available at: https://polityslovo.wordpress. com/.../s-khantíngton.

20. Khraban Í. A. (1999) Tsivíl'niy kontrol' nad zbroynimi silami v demokratichníy derzhaví (dosvíd SSHA í problemi Ukraïni): avtoref. dis. k.polít.n.: 23.00.02 / Kiïvs'kiy un-t ím. T. Shevchenka.

21. Tsivíl'niy kontrol'. Shcho take demokratichniy tsivíl'niy kontrol' civilian.defence-reforms.in.ua/what_is_democratic_civilian_.

22. Shamray V. O. (1999) Derzhavne upravlínnya víys'kovimi formuvannyami Voênnoî organízatsîi: stan ta tendentsîî rozvitku v suchasníy Ukraïní: avtoref. dis. d.derzh.upr.: 25.00.03 / UFDU.

23. Sherr D. (2000) Vimogi NATO ta Êvropeys'kogo Soyuzu shchodo demokratichnogo kontrolyu nad zbroynimi silami Reformuvannya Zbroynikh Sil Ukraïni: príoriteti, peredumovi ta perspektivi za materíalami mízhnarodnikh semínarív "Reformuvannya Zbroynikh Sil Ukraïni. Potrebi u zmínakh", Kiïv, 14-15 lyutogo 2000 r. ta "Vídnosini mízh zbroynimi silami, suspíl'stvom í derzhavoyu", Kiî́v.

24. Sherr D. (2004) Reforma sektora bezpeki v Ukraïní: zakhídniy poglyad Materíali ta dokumenti mízhnarodnogo semínaru 17-18 listopada "Osvítní aspekti realízatsiî́ TSíl'ovogo planu UkraỉnaNATO 2004 v strukturakh sektoru bezpeki derzhavi”. Dnípropetrovs'k, pp. 28-32.

25. Sherr D. (2004) Transformatsíya sektora bezpeki Dzerkalo tizhnya. no 23 (498).

Civilian (sometimes using the notion of democratic, civilian) control over the power and special structures of the state is a sign of the established democracy of the countries, which have legally fixed and traditionally legal norms of this control. Ukraine is only slowly, especially after the Orange Revolution and the Revolution of 
Virtue, on the path to building a democratic society. Therefore, in order to prevent the usurpation of power, the strengthening of police functions in the state, and the coming to power of radical elements, the concept of civil (democratic) control over the power and special structures of the state should be thoroughly investigated in order to organize their functioning in a democratic regime.

In the author of the article, the author of the genesis of understanding of civil control on the security forces and special structures of the state in military sciences, analysis of the contribution of foreign and foreign countries in this issue of this problem. The basic principles and tasks of civil control, directions of its realization are singled out. The definition of this concept is studied.

In the national science of public administration, the definition of "civilian control over the power and special structures of the state", as a social phenomenon, has not yet received adequate scientific coverage. Mostly, the study of this concept relates only to the possible functions of civil society and public authorities, but the consideration of the theory of control in the military and power organization of the state, the concept of its development, factors influencing its content and structure, as well as the problems of managing its components remains to be ignored. when performing specific tasks during the implementation of legal regimes of emergency and martial law. It is worth noting that without the coordination of the problems of civil and military management, proper defense of the state can not be ensured.

Often, academics reduce the civilian control of the security forces to three factors that are: civilian defense minister; broad parliamentary involvement in the implementation of the military budget control policy; openness of information on military issues. Civilian control is not limited to the functions of state institutions and the sphere of operation of the Ministry of Defense. The social structures of society must be involved in this process. In the future, it is necessary to clearly distinguish between the definitions of "democratic", "civil", and "civil" control of the state's power and special structures. 